\title{
Effect of bioagent formulations on progress of bacterial leaf blight disease of rice under field conditions
}

\author{
Gokil Prasad Gangwar \\ Department of Plant Pathology, G. B. Pant University of Agriculture and Technology, Pantnagar, 263 145, INDIA \\ E-mail: gokil_prasad@rediffmail.com
}

Received: August 8, 2013; Revised received: August 26, 2013; Accepted: September 4, 2013

Abstract: In the present study, effectiveness of different fungal (Trichoderma harzianum) and bacterial (Pseudo monas fluorescens) bioagent formulations in reducing progress of the bacterial leaf blight disease of rice under field conditions was studied and compared with chemical treatment and untreated check. The results exhibited that after 23 to 30 days after first application, bioagent formulations were more effective then chemical treatment in reducing progress of disease. Bioagent formulations exhibited long lasting effect in reducing progress of disease during Kharif, 2006 and 2007. Application of bioagent formulations resulted in significant reduction (60.5-142.8\%) in area under disease progress curve (AUDPC) as compared to check during Kharif, 2006 and 2007. Significant increase in grain yield (14.3 - $21.5 \%$ ) was observed with the application of bioagent formulations as compared to check during Kharif, 2006 and 2007.

Keywords: AUDPC, Bacterial leaf blight of rice, Disease progress curve, Infection rate, Pseudomonas fluorescens, Trichoderma harzianum

\section{INTRODUCTION}

Bioagents offers several advantages over chemical control like they are more stable without development of resistance in pathogen. Bioagents are non-phytotoxic and causes little disturbance in ecological balance. These are safe to environment, animal and human health and may also influence the ecological factors in the favour of crop or mitigating the effect of pathogen (Singh et al., 2005). Bioagents are reported to stimulate plant growth, even if there is no disease which results in better yield (Mishra and Sinha, 2000). Various antagonists (Trichoderma spp. T. harzianum, Bacillus spp., Pseudomonas spp., P. putida, P. fluorescence, Erwinia Herbicola and phylloplane microflora) are known to exhibits inhibitory effect on bacterial leaf blight disease of rice (Manmeet and Thind, 2002; Nzojiyobiri etal., 2003 and Rangarajan et al., 2003; Gangwar and Sinha, 2012a,b,c; Gangwar, 2012 and Gangwar, 2013). Bacterial leaf blight of rice has caused enormous losses in India and in all the rice growing areas of the world (Mew et al., 1993 and Anonymous, 2002). Outbreak of the disease is favoured by combination of metrological factors such as high temperature, high humidity, heavy rain fall, high light intensity and frequent typhoons (Murlidharan and Venkatarao, 1979). Mew et al., (1993) studied progress of disease related to plant growth stages like, seedbed, seedlings, panicle initiation, flowering and mature grain stages. Disease progress curves, apparent infection rate and AUDPC for bacterial leaf blight of rice have been developed by several workers (Adhikari et al., 1994; Ahmed et al., 1997 and Oña et al., 1998). Pattern of Disease progress curves (DPCs), apparent infection rate (AIR) and area under disease progress curve (AUDPC) provide better understanding of progress of disease. Analyzing these epidemiological parameters helps in predicting the epidemic on set, reaction of host plant, expected disease severity and yield loss. Effectiveness of bioagents against different plant diseases was reported by several workers by the assessment of infection rate and AUDPC (Elmer and McGovern, 2004; Verma and Dohroo, 2005 and Daghman et al., 2006). In the present investigation, effect of bioagent formulations and chemical treatment on the progress of bacterial leaf blight disease of rice was observed using different epidemiological parameters viz. disease progress curve (DPC), infection rate and area under disease progress curve (AUDPC).

\section{MATERIALS AND METHODS}

This experiment was conducted in $\mathrm{K}$ harif season during the years 2006 and 2007 at Crop Research Centre, G. B. Pant University of Agriculture and Technology, Pantnagar. Susceptible rice cultivar Jaya was used for the experiment. General agronomic practices were followed for the cultivation of experimental plots. Influence of two P. fluorescens formulations (Pf 83 and PBA2), two T. harzianum formulations (T. harzianum and PBA1) and one mixed formulation of $P$. fluorescens $+T$. harzianum 
formulation (PBA-3) on the progress of bacterial leaf blight of rice were studied along with chemical treatment [streptocycline $(0.03 \mathrm{~g}$ / litre water $)+$ copper oxychloride (1 g/litre water)] and untreated check. Bioagent formulations $\left(10^{6} \mathrm{cfu} / \mathrm{g}\right)$ were applied @ $10 \mathrm{~g} /$ litre water. All treatments were applied twice at 7 days interval in experimental plots using randomized block design.

Preparation of bioagent formulations: T. harzianum was mass multiplied on barnyard millet (Echinocloa frumentacae). Grains colonized by Trichoderma were air dried in open shade and ground with the help of Willy Mill to get fine powder. This powder was passed through 50 and 80 mesh sieves simultaneously to obtain spore powder. However P. fluorescens was mass multiplied on King's B broth. Both spore powder and broth culture diluted with talcum powder (mesh $=350$ with $95 \%$ whiteness) and $1 \%$ carboxyl methyl cellulose (CMC) to get desired concentration $\left(10^{6} \mathrm{cfu} / \mathrm{g}\right)$ of bioagents in the formulation.

I noculation of pathogen and treatment application: Pathogen was inoculated by clipping off the leaf tip @ $10^{6} \mathrm{cell} / \mathrm{ml}$ inoculum (Kauffman et al. 1973). Bioagent formulations and chemical treatment were applied next day of pathogen inoculation. Successive application of treatments was given after 7 days interval of first application. Data on percent disease severity recorded 14 days after first spray at 3 days interval. Disease progress curves were developed by plotting disease severity (\%) against time. Grain yield was recorded after harvesting.

Calculation for infection rate: Apparent infection rate was recorded for 3 days interval by using following formula (Vanderplank, 1963):

$r=\frac{2.3}{t_{2}-t_{1}} \log 10 \frac{x_{2}\left(1-x_{1}\right)}{x_{1}\left(1-x_{2}\right)}$

Where,

$\mathrm{x}_{1}=$ Disease index at time $\mathrm{t}_{1}$ (time of first disease rating)

$\mathrm{x}_{2}=$ Disease index at time $\mathrm{t}_{2}$ (time of second disease rating) $\mathrm{r}=$ Apparent infection rate

Disease severity (\%) was converted in to unit, by dividing with 100 and used in place of disease index for calculating apparent infection rate of bacterial leaf blight of rice.

Calculation for area under disease progress curve (AUDPC): Area under disease progress curve (AUDPC) was calculated by using following formula (Shanner and Finney, 1977):

AUDPC $=\frac{\left(\frac{D_{1}+D_{2}}{2} \times T\right)+\left(\frac{D_{2}+D_{3}}{2} \times T\right) \ldots \ldots . .\left(\frac{D_{n-1}+D_{n}}{2} \times T\right)}{n-1}$

Where, $\mathrm{D}=$ Percent disease severity at different dates $\left(\mathrm{D}_{1}, \mathrm{D}_{2}, \mathrm{D}_{3 \ldots \ldots \ldots} \mathrm{D}_{\mathrm{n}}\right)$

$\mathrm{T}=$ Time interval (days) between two observations $\mathrm{n}=$ Total number of observations

\section{RESULTS AND DISCUSSION}

Effect on disease progress curves: Disease progress curves were drawn for disease developing in experimental plots with different treatments. It was observed that DPCs for bioagent formulations revealed clear cut and equal length of lag, log and decline phase (Fig. 1). However, chemical treatment showed prolong lag and log phase. Decline phase was not observed with chemical treatment. In check, short lag and prolonged log phase were observed during K harif season of 2006. However, during Kharif 2007 DPCs for bioagent formulations showed prolong lag and log phase which were not distinct (Fig. 2) and decline phase were not observed. Chemical treatment showed prolong lag and log phase. Check plots showed short lag phase followed by sharp increased in log phase with no decline phase.

A disease progress curve, AUDPC and the epidemic rate were calculated by Monaco et al. (1999) with Saprobic fungi (Nigrospora spp., Penicillium sp. b, Chaetomium globosum, Cladosporium cladosporioides and Trichoderma polysporum) which inhabited Alternaria solani in tomato phylloplane. In the present study, disease progress curves depicting progress of bacterial leaf blight of rice, under field condition were developed for bioagent formulations and compared with chemical treatments and untreated check (Fig. 1, 2). DPCs of bioagent formulations were showed short leg and log phase which was followed by prolong decline phase. Short leg and log phase may be because bioagent formulations did showed effectivity sooner as they applied and later they showed higher effectivity in reducing progress of disease and hence resulted prolong decline phase. Delayed and prolong leg phase was showed by chemical treatment showing instant effectivity of chemical treatment which was not long lasting and hence showed sharp log phase due to higher progress of disease. Decline phase was absent as total mortality of leaves occurred. DPC for untreated check, showed very short leg phase which was followed by long log phase showing fastest progress of disease. After killing all tissues sharp decline phase was observed as there is no fresh tissues available for further infection. However, DPC with chemical treatments was lagging behind the DPCs with bioagent formulations showing higher effectivity of chemicals over bioagent formulations at initial stage of disease progress. Later DPC of chemical treatment crossed over the DPCs of bioagents and crossing above. This may be explained as during later stage of disease progress bioagents have got sufficient time for population build up and/or induces resistance and hence showed higher effectivity over chemical treatment in due course of time. The effectivity of bioagent formulations was long lasting while, chemical showed effectivity in 


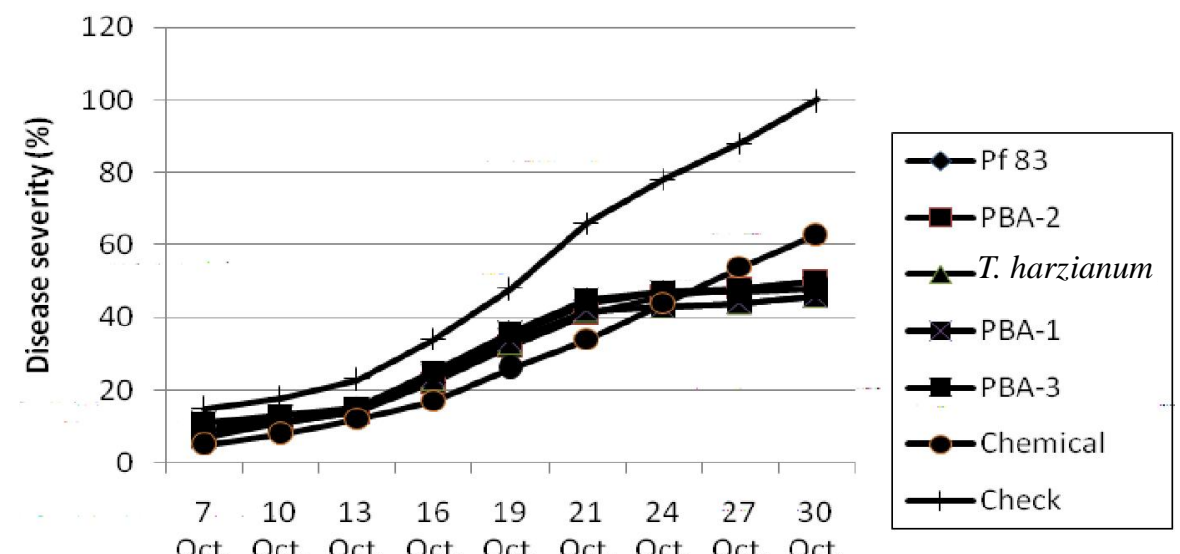

Date of observation (2006)

Fig. 1. E ffect of application of bioagent formulations on progress of bacterial leaf blight disease severity, during K harif 2006. *M ean of three replications; P. fluorescens formulations (Pf 83 and PBA-2), T. harzianum formulations (T. harzianum and PBA-1) and T. harzianum + P. fluorescens formulation (PBA-3).

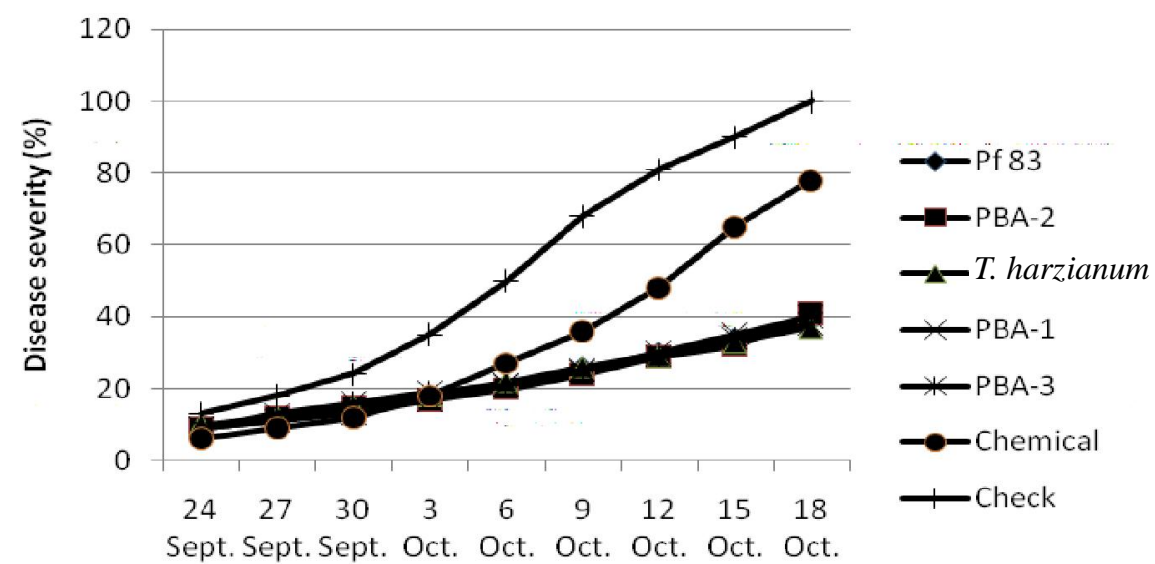

Date of observation (2007)

Fig. 2. Effect of application of bioagent formulations on progress of bacterial leaf blight disease severity, during K harif 2007. ${ }^{*}$ M ean of three replications; P. fluorescens formulations (Pf 83 and PBA-2), T. harzianum formulations (T. harzianum and PBA-1) and T. harzianum + P. fluorescens formulation (PBA-3).

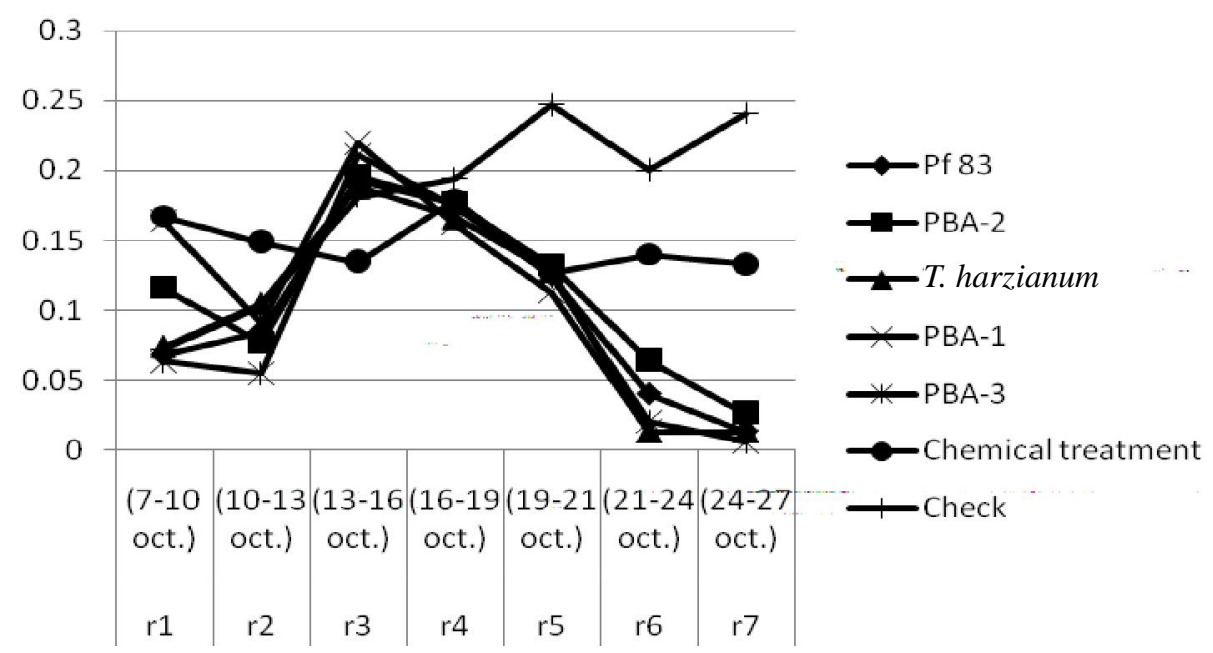

Fig. 3. Effect of application of bioagent formulations on infection rate of bacterial leaf blight disease at three days interval during $K$ har if 2006. " $M$ ean of three replications; P. fluorescens formulations (Pf 83 and PBA-2), T. harzianum formulations (T. harzianum and PBA-1) and T. har zianum + P. fluorescens formulation (PBA-3) 


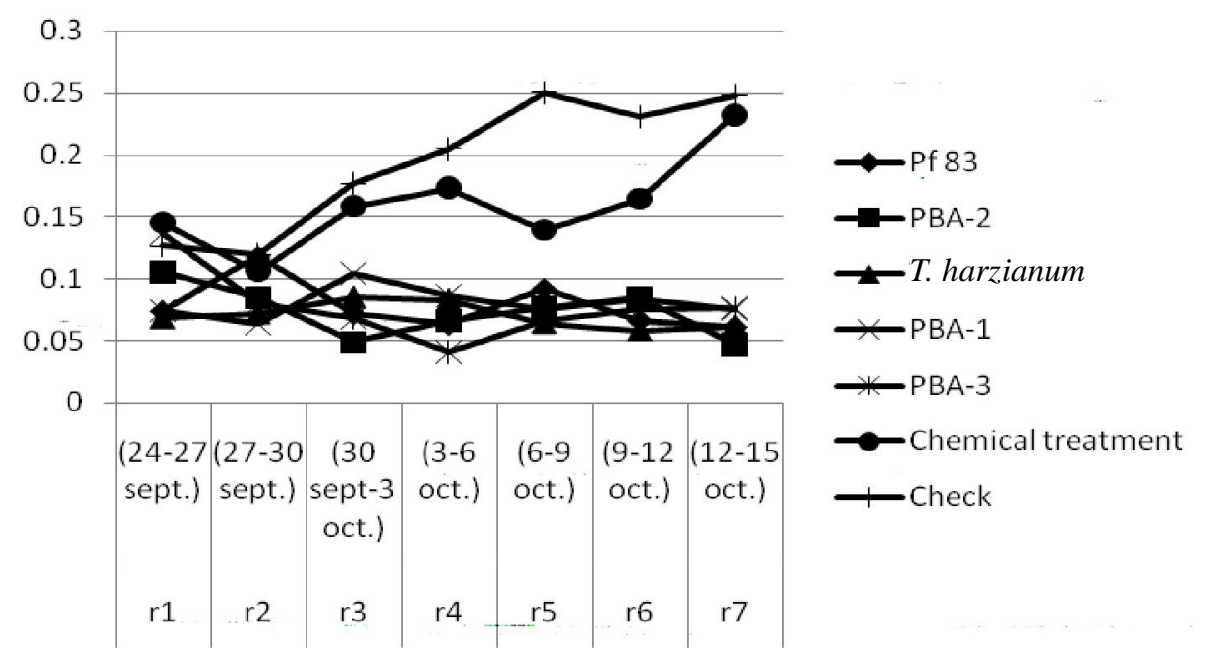

Fig. 4. Effect of application of bioagent formulations on infection rate of bacterial leaf blight disease at three days interval during K harif 2007. *M ean of three replications; P. fluorescens formulations (Pf 83 and PBA-2), T. harzianum formulations (T. harzianum and PBA-1) and T. harzianum + P. fluorescens formulation (PBA-3)

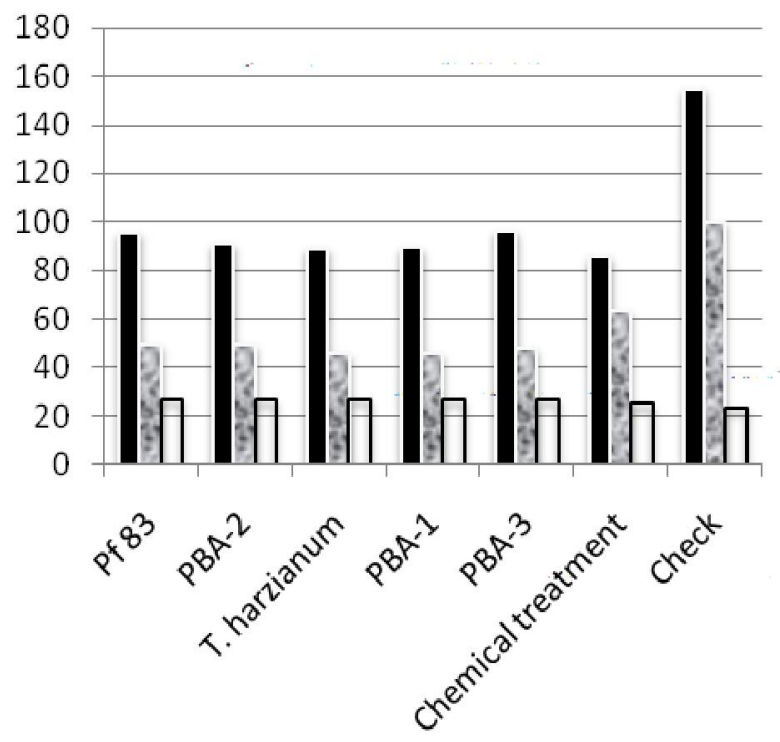

- AUDPC

a Final disease severity (\%)

$\square$ Grain yield (q/h)

Fig. 5. Effect of application of bioagent formulations on area under disease progress curve (AU DPC) for bacterial leaf blight disease and grain yield ( $\mathrm{q} / \mathrm{h}$ ) of rice during $\mathrm{K}$ harif $2006 .{ }^{*} \mathrm{M}$ ean of three replications; $\mathrm{P}$. fluorescens for mulations (Pf 83 and PBA2), T. harzianum formulations (T. harzianum and PBA-1) and T. harzianum + P. fluorescens formulation (PBA-3).

checking the progress of disease for a certain period of time.

E ffect on infection rate: During cropping season K harif 2006, infection rates were calculated for all treatments. At early stage of disease progress $\left(r_{1}, r_{2}\right.$ and $r_{3}$ ) were found statistically similar to check plots. However, at later stage of disease progress significantly reduced infection rates $\left(\mathrm{r}_{4}, \mathrm{r}_{5}, \mathrm{r}_{6}\right.$ and $\left.\mathrm{r}_{7}\right)$ with application bioagent formulations were observed as compared to check (Fig. 3). Reduced infection rates in late stages of disease progress $\left(r_{6}\right.$ and $r_{7)}$ were observed for all bioagents as compared to chemical treatment and check. During cropping season K harif 2007, at early stage of disease progress bioagent formulations PBA-3, Pf 83 and chemical treatment showed $r_{1}$ and $r_{2}$ statistically similar to check. As disease progressed, significantly lowered infection rates $\left(r_{3}, r_{4}, r_{5}\right.$, $r_{6}$ and $r_{7}$ ) were observed with application of bioagent formulations as compared to check and chemical treatment (Fig. 4).

Effectiveness of bioagents against different plant diseases was reported by several workers (Elmer and McGovern, 2004; Verma and Dohroo, 2005 and Daghman et al., 2006) by the assessment of infection rate and AUDPC. Minimum apparent infection rate, decreased AUDPC and increased seed germination was observed by Verma and Dohroo (2005) against F usarium wilt of pea with the bioagents, T. viride and T. harzianum as compared to control. In the present study, infection rates during early stage of disease progress $\left(r_{1}, r_{2}\right.$ and $r_{3}$ during K har if 2006 and $r_{1}$ and $r_{2}$ during K harif 2007) with bioagent formulations were equal to that of check plots (Tables 1 , 2 ). This may be because bioagent formulations were not 


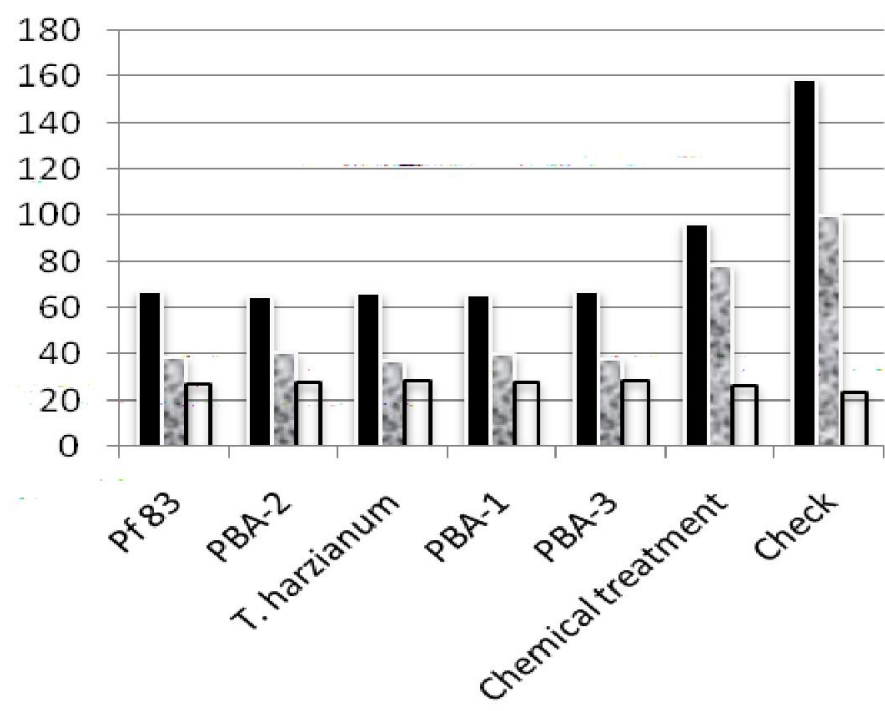

\section{AUDPC}

ainal disease severity $(\%)$

$\square$ Grain yield $(\mathrm{q} / \mathrm{h})$

Fig. 6. Effect of application of bioagent for mulations on ar ea under disease progress curve (AUDPC) for bacterial leaf blight disease and grain yield ( $q / h$ ) of rice during K har if 2007. ${ }^{*}$ M ean of three replications; P. fluorescens formulations (Pf 83 and PBA2), T. harzianum formulations (T. harzianum and PBA-1) and T. harzianum + P. fluorescens formulation (PBA-3).

effective in reducing progress of disease in early stage. However, in later stage of disease progress infection rates $\left(\mathrm{r}_{4}, \mathrm{r}_{5}, \mathrm{r}_{6}\right.$ and $\mathrm{r}_{7}$ during K harif 2006 and $\mathrm{r}_{3}, \mathrm{r}_{4}, \mathrm{r}_{5}, \mathrm{r}_{6}$ and $r_{7}$ during K harif 2007) with bioagent formulations were lowered as compared to check which reveals higher effectivity of bioagent formulations over check. Infection rates, $r_{6}$ and $r_{7}$ during $K$ harif 2006 and $r_{3}, r_{4}, r_{5}$, $r_{6}$ and $r_{7}$ during $K$ harif 2007 was found lower as compared to chemical treatment showing higher effectivity of bioagent formulations over chemical treatments in later stage of disease progress. Infection rate declined in case of bioagents it might be due to population build up of antagonists and/or induced resistance. Increasing infection rate over time observed in case of chemical is expected as their impact was quick and short lived and indicating decrease in the performance of chemicals over time.

Effect on area under disease progress curve (A UDPC): All treatments exhibited significantly lowered AUDPC as compared to check (Fig. 5) during K harif 2006. Application of T. harzianum Formulation showed maximum reduction (42.34\%) in AUDPC followed by PBA$1(42.22 \%)$ and PBA-2 (41.20\%). During Kharif 2007, all treatments were effective in reducing AUDPC as compared to check and chemical treatment (Fig. 6). Maximum reduction in AUDPC was recorded with Application of PBA-2 formulation (58.81\%) which was followed by PBA-1 (58.22\%) and T. harzianum (57.98\%). Based on disease incidence expressed as the AUDPC, Daghman et al. (2006) concluded that the T. harzianum (UPM40) dry preparation was effective in protecting the seeds and seedlings against pre and post emergence damping-off caused by Rhizoctonia solani in leaf mustard (Brassica rapa). In the present study, during cropping season $\mathrm{K}$ harif 2006, PBA-2, Pf 83 and PBA-3 formulations showed lower values of AUDPC as compared to chemical treatment and check (Fig. 5). Under field condition, bioagent formulations were more effective than chemical treatments in reducing amount of disease. However during cropping season K harif 2007, all bioagent formulations showed significantly reduced AUDPC as compared to check and chemical treatment (Fig. 6). This revealed higher effectivity of bioagent formulations over chemical treatment under field condition. Elmer and McGovern (2004) reported reduction in the AUDPC when bioagents were applied following combinations of a fungicide treatment or tank-mixed with a fungicide which indicated the suppression of F usarium wilt of cyclamen. Raupach et al. (1996) observed significantly lower AUDPC with P. fluorescens strain 89B-27 than in the nonbacterized control while working on induced systemic resistance in cucumber and tomato against cucumber mosaic cucumovirus using P. fluorescens strains $89 \mathrm{~B}-27$ and Ser ratia marcescens strain 90-166.

\section{Conclusion}

The present study concluded that after a period of time of 23 to 30 days after first application, all bioagent formulations were more effective then chemical treatment in reducing progress of disease. Bioagent formulations exhibited long lasting effect in reducing progress of disease in both the crop seasons. Their applications resulted in significant reduction in area under disease progress curve (AUDPC) as compared to check and chemical treatment. Further study is needed to understand the mechanism of reduction in epidemiological parameters due to application of these bioagent formulations.

\section{REFERENCES}

Adhikari, T.B., Mew, T.W. and Teng, P.S. (1994). Progress of bacterial blight on rice cultivars carrying different $X a$ genes 
for resistance in the field. PI. Dis., 78(1): 73-77.

Ahmed, H. U., Finckh, M. R., Alfonso, R. F. and Mundt, C. C. (1997). Epidemiological effect of gene deployment strategies on bacterial blight of rice. Phytopathology, 87:66-70.

Anonymous (2002). FAO statistic India. File:///A/FAOSTAT Data Base results.com

Daghman, I. M., Sariah, M., Kadir, J., Zainal-Abidin, M. A. and Rosenani, A. B. (2006). Dry preparation of Trichoderma harzianum for controlling rhizoctonia damping-off in Brassica rapa. International Journal of Agricultural Research, 1: 590-596.

Elmer, W H. and McGovern, R. J. (2004). Efficacy of integrating biologicals with fungicides for the suppression of Fusarium wilt of cyclamen. Crop Protection, 23: 909-914.

Gangwar, G. P. (2012) Efficacy of commercial formulations of bioagent against bacterial leaf blight of rice. Ann. PI. Protec. Sci., 20(2): 389-391.

Gangwar, G. P. (2013). Efficacy of bioagents application rate against bacterial leaf blight of rice. Ann. Pl. Protec. Sci., 21(1): 206-208.

Gangwar, G. P. and Sinha, A. P. (2012c). Effect of time of application on fungal and bacterial bioagents against bacterial leaf blight of rice. Agric. Sci. Digest., 32 (2): 123-127.

Gangwar, G.P. and Sinha, A.P. (2012a). Comparative antagonistic potential of fungal and bacterial bioagents against isolates of Xanthomonas oryzae pv. oryzae. Ann. PI. Protec. Sci., 20(1): 154-159.

Gangwar, G.P. and Sinha, A.P. (2012b). Evaluation of Trichoderma spp. and fluorescent pseudomonads for the management of bacterial leaf blight of rice. Indian Phytopath., 65 (1): 89-91.

Kauffman, H. E., Reddy, A. P. K., Heisk, S. P. V. and Maraca, S. D. (1973). An improved technique for evaluating resistance of rice varieties to Xanthomonas oryzae. Plant D is. R ep., 57: 537-541.

Manmeet, M. and Thind, B.S. (2002). Management of bacterial blight of rice with bioagents. Plant Dis. Res., 17(1): 21-28.

Mew, T. W., Alvarez, A. M., Leach, J. E. and Swings, J. (1993). Focus on bacterial blight of rice. Plant Dis., 77(1): 5-12.

Mishra, D.S. and Sinha, A. P. (2000). Comparative efficacy of some biocontrol agents applied as seed or soil treatment on seedling infection of rice caused by Rhizoctonia solani. In: $52^{\text {nd }}$ Annual meeting of Indian Phytopathological Society and National Symposium on "Role of R esistance in Intensive Agriculture" held at, Karnal, Haryana.

Monaco, C. I., Nico, A. I., Mitidieri, I. and Alippi, H. E. (1999). Saprobic fungi inhabiting tomato phylloplane as possible antagonists of Alternaria solani. Acta Agronomica Hungarica, 47: 397-403.

Murlidharan, K. and Venkatarao, G. (1979). Bacterial leaf blight of rice in Nellore district, Andhra Pradesh. Indian Phytopath. 32: 483-485.

Nzojiyobiri, J. B., Xu, T., Song, F.M. and Shen, Y. (2003). Resistance induced by Trichoderma harzianum NF9 against Magnaporthe grisea and Xathomonas oryzae pv. oryzae in rice. Chinese J ournal of Biological Control, 19(3): 111114.

Oña, I., Vera Cruz, C. M., Nelson, R. J., Leach, J. E., and Mew, T. W. (1998). Epidemic development of bacterial blight on rice carrying resistance genes $\mathrm{Xa}-4, \mathrm{Xa}-7$, and $\mathrm{Xa}-10$. Plant Dis., 82:1337-1340.

Rangarajan, S., Saleena, L. M., Vasudevan, P. and Nair S. (2003). Biological suppression of rice diseases by P seudomonas spp. under saline soil condition. Plant and Soil, 251(1): 73-82.

Raupach, G. S., Liu, L., Murphy, J. F., Tuzun, S. and Kloepper, J. W. (1996). Induced systemic resistance in cucumber and tomato against cucumber mosaic cucumovirus using plant growth-promoting rhizobacteria (PGPR). Plant D is., 80: 891894.

Shanner, G. and Finney, R. F. (1977). The effect of nitrogen fertilization on the epression of slow mildowing resistance in Knox Wheat. Phytopathology, 67:1051-1056.

Singh, U. S., Mishra, D. S., Zaidi, N. W., Varshney, S., Sharma, R. and Singh, N. (2005). Potential and effectiveness of fungi and bacteria as biocontrol agents for plant disease management. In: Integrated pest management: principles and application Volume 1: Principles (Singh, A., Sharma, O.P. and Garg, D.K. ed.), CBS, New Delhi, India.

Vanderplank, J. E. (1963). Plant diseases: Epidemics and control. Academic Press. New York, London, pp. 349.

Verma, S. and Dohroo, N.P. (2005). Comparative efficacy of biocontrol agents against $F$ usarium wilt of pea. Integrated plant disease management Challenging problems in horticultural and forest pathology, Solan, India, pp. 93-99. 